ARKADIUSZ LEWANDOWSKI

Instytut Politologii UMK

\title{
Europa: wczoraj, dziś, jutro
}

akakolwiek zmiana czy to rewolucyjna, czy też ewolucyjna niesie ze sobą konsekwencje. Przeważnie rzeczywiste efekty nie są widoczne natychmiastowo. Potrzebna jest perspektywa upływającego czasu. Czasu liczonego nie w godzinach ani dniach, lecz czasu mierzonego dekadami bądź też stuleciami. Karl Jaspers konstruując własny projekt czasu osiowego, poddawał jednocześnie pod zastanowienie sprawę stadium, w jakim znajduje się współczesna cywilizacja. Zastrzegał jednak, iż odpowiedź nie jest możliwa bez wyjścia poza współczesny czas. Sam bowiem pojmując za szczególny okres czas pomiędzy VIII a V wiekiem przed Chrystusem, spoglądał na niego z perspektywy dwóch i pół tysiąca lat ${ }^{1}$. Upływający czas, jak sugeruje Ryszard Legutko, w zależności od jego rozpiętości pozwala pojmować rzeczywistość na trzy różne sposoby. Najszerzej traktowana rzeczywistość tożsama jest $z$ bytem a zmiana dotyczyć będzie rzeczy wiecznych. Czas traktowany jest zatem bardzo rozlegle. W sensie drugim rzeczywistość/czas ograniczona zostaje do cywilizacji tworzonej przez człowieka. W tym miejscu perspektywa czasowa się zawęża, jednak nadal posługujemy się raczej miarą wieków aniżeli lat. W trzeciej koncepcji czasu, celem staje się obrona realności, do której przyzwyczaił się człowiek ${ }^{2}$. Dlatego też zmiana może dotykać trzech różnych zakresów życia człowieka. Może wystąpić modyfikacja dotycząca istoty człowieczeństwa, cywilizacji bądź jednostki żyjącej „tu i teraz”. Tłumaczony tekst Denisa de Rougemotna stara się zaprezentować czytelnikowi zmianę rozpatrywaną na poziomie środkowym, ukazując ducha Europy na przestrzeni pierwszej połowy XX wieku. Można zadać pytanie czy pół wieku to rzeczywiście odpowiednio długi czas dla zauważenia zmian? Odpowiedź jest prosta: ilość wydarzeń i ich skala nie mogła pozostawić „starego świata” bez zmian. Należałoby raczej zapytać jak głębokie zmiany zaszły? Artykuł napisany został w 1951 roku na prośbę "Saturday Review of Literature" do numeru „Ameryka i europejski umysł”. W roku 1970 został z kolei wydany jako część pracy Le cheminement des esprits: l'Europe en jeu II ${ }^{3}$.

Cała teoria zagadnienia czasu osiowego przedstawiona została polskiemu czytelnikowi w K. Jaspers, O źródle i celu historii, Kęty 2006.

R. Legutko, Konserwatyzm, „Res Publica”, nr 3, 1998, s. 146.

D. de Rougemont, Le cheminement des esprits : l'Europe en jeu II, Neuchatel 1970. 
Denis de Rougemont (1906-1985) wywodził się z protestanckiej rodziny. Pierwsze nauki pobierał w szkole w rodzinnym Neuchatel. Swoją edukację uwieńczył na wydziale nauk społecznych Uniwersytetu w rodzinnej miejscowości ${ }^{4}$. Dla późniejszych koncepcji formułowanych przez de Rougemonta ważnym wydarzeniem był okres pobytu w Paryżu (lata 1930-1934), kiedy to brał on udział w formowaniu się ruchu paternalistycznego. W okresie tym żywo zainteresował się twórczością Karla Bartha oraz Sørena Kierkegaarda ${ }^{5}$. Szwajcarski pisarz i publicysta, założyciel Le Centre Européen de la Culture, w Polsce znany jest $\mathrm{z}$ takich prac jak List otwarty do europejczyków $w^{6}$, Miłość a świat kultury zachodniej ${ }^{7}$, Mity o mitości $i^{8}$ oraz Udział diabła ${ }^{9}$. Oprócz twórczości literackiej imponująco przedstawia się działalność na rzecz procesu tworzenia federacji europejskiej. Był on redaktorem deklaracji końcowej pierwszego Kongresu Europy w 1948 roku. Uważany za kluczowego ideologa sfederalizowanej Europy w ciągu blisko 40 lat nieustannie pisał na temat Europy. Warto też nadmienić, iż był on bliskim przyjacielem i współpracownikiem Józefa Retingera ${ }^{10}$.

Poruszane w jego twórczości zagadnienie fenomenu szeroko rozumianej europejskiej tożsamości kulturowej opiera się na pesymistycznej wizji kondycji ducha Europy. Źródeł kryzysu Starego Kontynentu doszukuje się on w racjonalizmie, który niszcząc religię, przyczynił się do „wdarcia mrocznych sił do ludzkich siedzib"11. Zauważył, iż Europa potrzebowała zmian w wymiarze fundamentalnych zasad i ostatecznego celu, do którego ma dą$\dot{z ̇ y c ́}^{12}$. Zastąpienie „Opatrzności wiarą w automatyczny postęp”, wiara we wrodzoną dobroć człowieka i zapomnienie o jego złej naturze, wyeliminowanie poczucia tragiczności i zastąpienie go przez poszukiwanie wygody i cnót przeciętności to części składowe XIX-wiecznego przewartościowania europejskiej duszy ${ }^{13}$. Przewartościowania, które było pierwszym krokiem do tragedii dwóch wielkich wojen.

Autor Udziału diabła porównując zmiany w pierwszej połowie ubiegłego wieku, automatycznie prowokuje nas do zadania pytania, co zmieniło się

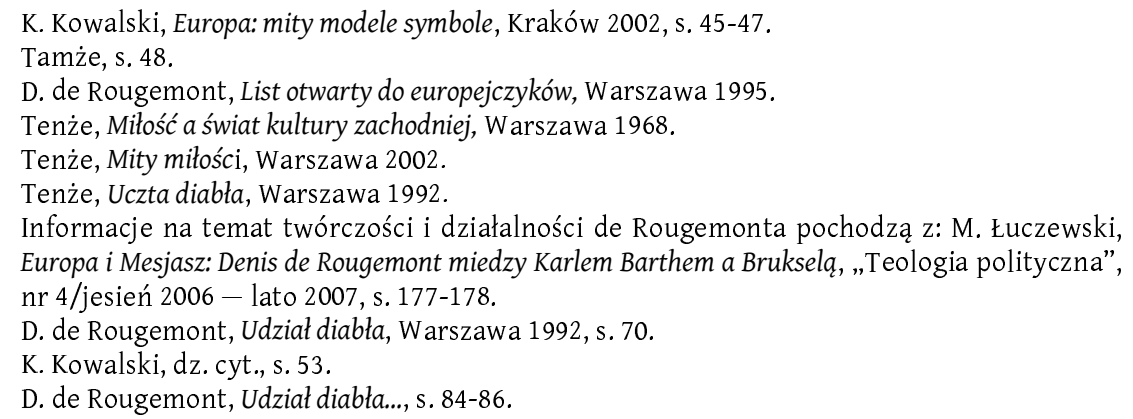


po kolejnych pięćdziesięciu latach? Czy Europa po wojennej zawierusze powróciła do swoich korzeni? Co zmieniło się z duchem europejskim nie zaś $z$ instytucjami politycznymi? Wielką niewiadomą jest jak orędownik integracji europejskiej odniósłby się do dzisiejszego kształtu Europy. W tej sferze można znaleźć zjawiska, które na pewno nie znalazłyby jego uznania. Chociażby problem, jaki napotkała próba wprowadzenia zapisów odnoszących się do chrześcijaństwa do preambuły Traktatu ustanawiającego Konstytucję dla Europy wskazuje, iż Europa - w szczególności dla de Rougemonta, który był zwolennikiem powrotu do „radykalnego chrześcijaństwa”" chora. Infekcję - podążając za myślą szwajcara - stanowi również wolnościowe podejście do kwestii moralnych będące konsekwencją laicyzacji Europy. Jak pisał autor Mitów o mitości: „bądźcie wolni, ot tak sobie, bezwarunkowo i bez celu, po to, aby robić, co wam się podoba, a prawdopodobnie będziecie robić to, co podoba się Diabłu. Ale gdy będziecie wolni po to, aby odnaleźć i wypełnić powołanie dane wam przez Boga, wyzwolicie się z łańcucha uwarunkowań, które narzucają wam czas i miejsce narodzin, rasa, własne błędy i panujące opinie” ${ }^{15}$. Człowiek współczesny „pragnie być panem swego szczęścia (...) czuć z czego się ono składa, analizować je i poznać jego smak"16. "Jest opętany ideą łatwego szczęścia"17. Wydaje się, iż od czasu przelania tych refleksji na papier (połowa XX wieku) kondycja przeciętnego mieszkańca Europy niewiele się zmieniła.

Z twórczości de Rougemonta wypływa recepta dla Starego Kontynentu. Jest nim wspólnota „Europejczyków”. Wobec fascynacji de Rougemonta tematyką teologiczną porównać można jego wizję ze średniowieczną „Christianitas", w której to Europa tworzyła jednolity kulturowo organizm. Jak sugeruje Michał Łuczewski, federalizm europejski był wedle de Rougemonta przeniesieniem na polityczny grunt ekumenizmu. Głównym wrogiem, który musiałby jednak być pokonany, aby urzeczywistnić cel wspólnej Europy, był nacjonalizm. Niestety autor Mitów miłości utożsamia każdy nacjonalizm z totalitarnym systemem. Twierdzi on, iż naród traci swój romantyczny prestiż. Interesy państwowe zaś przesłaniają uczucia oraz poczucie honoru elity" ${ }^{\prime 18}$. Jako personalista nie zgadzał się na przeniesienie centrum uwagi z jednostki na naród bądź państwo. Nacjonalizm, wedle szwajcarskiego pisarza, prowokował do zburzenia jedności europejskiej kultury ${ }^{19}$. Kultury, która miała stać

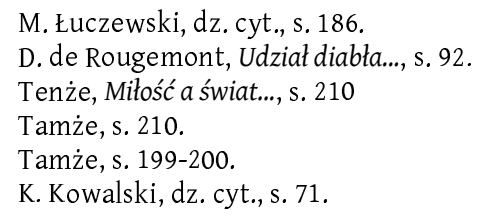


się podstawą dla nowej Europy, w której istnieć będzie „naród europejski”. De Rougemont podaje przykład literatur narodowych, które, jak sugeruje, powstają w wyniku rozróżnienia literatury europejskiej ${ }^{20}$.

Źródłem dla przyszłej federacji miały być autonomiczne wspólnoty i regionalne stowarzyszenia ${ }^{21}$. Pokonanie nacjonalizmu przebiegałoby zatem oddolnie. W tym miejscu jednak koncepcja Szwajcara natrafia na problem zderzenia z realizmem. De Rougemont podejmując próby tworzenia europejskości, sięga zatem po metody odgórne. Proponując programy szkolnictwa europejskiego, krzewienia tego, co europejskie a nie narodowe, zmierza w konsekwencji do stworzenia "narodu europejskiego" metodami dalekimi od naturalnych. Hasło „Europy nie będzie, jeśli nie będzie europejczyków”22 sugeruje, iż faktycznie wpierw trzeba stworzyć to, co jest „europejskie”, a następnie na tym gruncie wykreować europejczyka.

Jak się jednak wydaje nie byłby to naturalny twór. Narody tworzą kulturę Europy poprzez swoją różnorodność. Współcześnie, po 50 latach od zakończenia wojny ponownie mamy do czynienia z renacjonalizacją polityki wewnątrz Wspólnoty Europejskiej. Paradoksalnie, dzieje się to w czasie, kiedy wizja państwa europejskiego preferowana przez elity polityczne, nierozumiana jednak przez społeczeństwa jest najbliżej realizacji. Stosowane przez autora Listu otwartego do europejczyków negowanie realności istnienia narodów okazało się błędne. W perspektywie całego XX wieku narody są rzeczywiste a federacja iluzją ${ }^{23}$.

Zmiany, które zaszły w Europie w okresie tak przed, jak i w czasie II Wojny Światowej, mają swoje konsekwencję także w drugiej połowie XX wieku. Rozpoznanie kryzysu ducha europejskiego dokonane przez de Rougemonta było trafne. Jednak propozycje ratowania Europy nie sprawdziły się. Dziś możemy stwierdzić: proponowanie tworzenia jednego narodu Europy opartego na wspólnym fundamencie spowodowało efekt odwrotny. Wizja Europy opartej na chrześcijaństwie z przebudzonym duchem wydaje się jeszcze odleglejsza niż pół wieku temu. Gdy de Rougemont myślał, że kryzys ma się ku końcowi, on właśnie się budził. Głębokość zmian dostrzeżona mogła być dopiero po stu latach, kiedy to widoczne są nieodwracalne ich skutki. Sama Wspólnota Europejska porzuciła jakąkolwiek myśl o chrześcijańskich czy też metafizycznych podwalinach. Celem jej funkcjonowania nie jest wspólnota Europejczyków a raczej tworzenie państwa europejskiego, którego skutkiem ubocznym będzie człowiek europejski. Paradoksalnie, ten sam

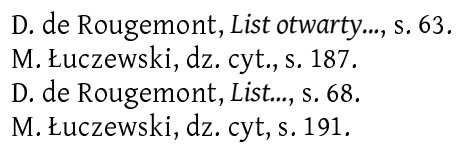


mechanizm powodował sprzeciw głównego ideologa integracji europejskiej wobec państw narodowych.

A R K A D I U S Z L E W A N D O W S K I 